\title{
Citizenshit: The Right to Flush and the Urban Sanitation Imaginary
}

\section{Margaret Morales}

Corresponding Author: margaret.c.morales@gmail.com

Leila Harris, Gunilla Öberg

\section{University of British Columbia, 2014}

Final version: Morales M., L. Harris, and G. Öberg (2014) Citizenshit: the right to flush and the urban sanitation imaginary. Environment and Planning A, 46(12): 2816 - 2833.

Citations of this work should use the final version as noted above 


\section{TABLE OF CONTENTS}

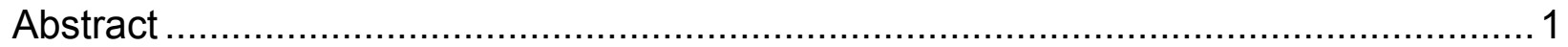

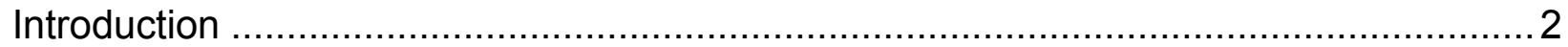

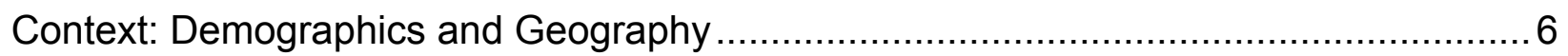

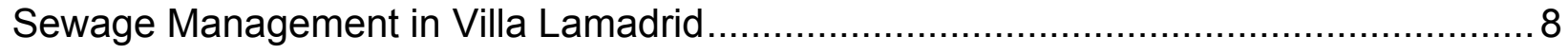

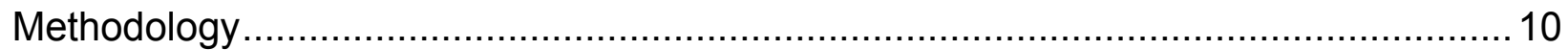

Reactions to the Dry Sanitation Solution.................................................... 12

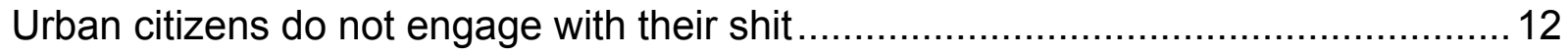

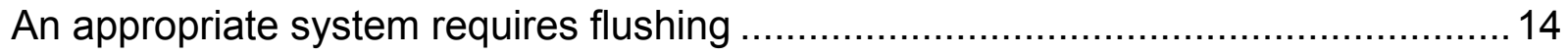

Sanitation solutions that require direct user engagement signify rural, underdeveloped,

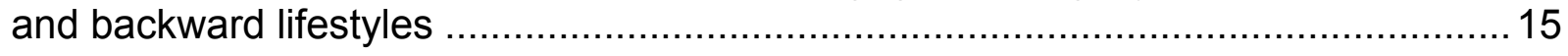

Urban sanitation service is a state responsibility - not a local one ....................... 16

Discussion: A Citizen's Shit is Invisible ...................................................... 19

Conclusion: How the Urban Sanitation Imaginary May Help Ground Our Sanitation

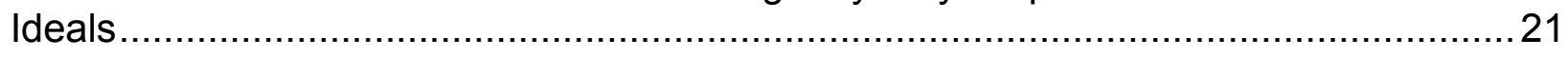

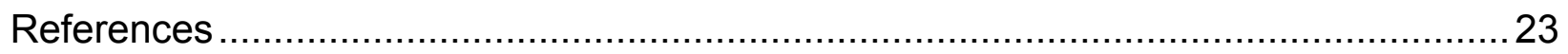




\section{ABSTRACT}

For many in the global North, urban life means that your shit is not your problem. We foreword that a possible reason for the global sanitation failure in urban areas is a disconnect between sanitation expectations - what we term the urban sanitation imaginary - and the practices required by proposed sanitation solutions. The case study presented here is based on interviews with residents of Villa Lamadrid, a marginalized neighborhood in Buenos Aires, Argentina, which faces significant public health impacts from an inadequate sewage management system. We solicited feedback regarding specific sanitation technologies frequently prescribed for poor urban communitiesamong them a urine diversion dry toilet (UDDT) with dehydration vaults. Even as this system is posited as 'sustainable' for the context of Villa Lamadrid in terms of ecological and economic factors, conversations with residents revealed why this option might not be sustainable in terms of social expectations. Based on interviews with community members we have defined four aspects of residents' urban sanitation imaginaries that we consider highly relevant for any consideration of sanitation solutions in this context: 1) an urban citizen does not engage physically or mentally with their shit or its management; 2) an appropriate urban sanitation system requires flushing; 3) systems that require user's engagement with their shit and its management signify rural, underdeveloped, and backward lifestyles; and 4) urban sanitation is a state responsibility, not a local one. Highlighting the urban sanitation imaginary methodologically and analytically goes beyond a discussion of culturally and contextually appropriate technologies. It examines linkages between user expectations and notions of urban citizenship and modernity. Ultimately it also draws attention to the socio-political dynamics and environmental justice issues embedded in discussions of sanitation and hygiene. While some of our results are specific to the Villa Lamadrid context, our research more generally suggests the need to consider sanitation imaginaries to reframe the discussion on sanitation interventions, particularly in underserved and impoverished urban areas.

Key words: sanitation imaginary, flush, Argentina, urban, citizenship, dry toilet 


\section{INTRODUCTION}

For many in the global North, urban life means that your shit ${ }^{1}$ is not your problem. While this reality is not widespread in the South, distance from shit, facilitated by a connection to a centralized, water-borne, linear end-of-pipe sanitation system, may nonetheless be essential to imaginaries of urbanity and modernity. In this paper we examine how expectations of sanitation in urban settings - what we term the urban sanitation imaginary - influence perceptions of what constitutes an appropriate solution to sewage management in these areas. Ultimately our interests lie in how this may influence urban planning for marginalized communities and slum dwellers.

Demographic shifts following rapid urbanization have profound implications for urban infrastructure. Sewerage infrastructure in particular often faces pronounced challenges from rapidly growing demand (Foppen and Kansiime, 2009). Unequal access to improved sewerage and water services has often been thought of as a temporary phenomenon-a symptom of a transitional period as cities entered a new modern age - soon to be remedied by continued urban planning and investment (Davis, 2004; Gandy, 2004; 2006). However, differences in access have instead widened in recent decades (Davis, 2004; Gandy, 2004; Mamdani, 1996). Even with considerable investments, an estimated $1 / 5^{\text {th }}$ of the global urban population still lacks access to improved sanitation (JMP, 2012). This widening infrastructural gap in many fast growing urban centers is not only a result of financial and technical challenges; it is also a sign of continuing power inequalities, revealing stark differences between service provision for elites, and those who have relatively little political and economic influence (Bakker, 2010; McFarlane, 2008b; Swyngedouw, 2004). Referring to water access, Gandy (2004), drawing on the work of Mamdani (1996), considers access discrepancies a "legacy of an incomplete modernity which rested on a brutal distinction between 'citizens' who could lay claim to potable water and mere 'subjects' who were left to make do as best they could" (p. 368). We extend this to apply to adequate sanitation infrastructure as well (see also: Appadurai, 2002; Chatterjee, 2004).

In many parts of the world, conventional sewage management relies on waterborne transport to carry waste to a central treatment facility or disposal site. While this model has become the 'gold standard' for sewage management in many urban areas (Jewitt, 2011; Penner, 2010), it has also been termed "an implicitly anti-poor technology" (Paterson et al, 2007: 901) owing to its high water and energy consumption and dependence on large infrastructure (also: Jewitt, 2011; Mohit and Ludwig, 2000; Nhapi, 2004; Niemczynowiez, 1993). The centralized, so called 'linear end-of-pipe' sewerage model, is particularly difficult to implement in informal communities where settlements may be dense and in flux, built in precarious areas (riverbanks or low-lying marshlands), and have minimal access to financial or other resources (Beall et al, 2011; Gandy, 2004; Swyngedouw, 2004).

\footnotetext{
${ }^{1}$ In concert with other scholars (Black and Fawcett, 2008; George, 2009; Mehta and Movik, 2011), we use the word shit openly in this research to counter taboos that often lend to the difficulty of sanitation work.
} 
Considerable effort has been invested in the development of novel and 'low-tech' systems that are perceived to be better suited to the needs of impoverished and informal communities (witness the Gates Foundation's 'Reinvent the Toilet Challenge,' 2012). To meet public health needs, as well as financial, and technical challenges presented in these communities, proposed solutions tend to be decentralized, require minimal resource inputs (financially, technologically, infrastructurally, or otherwise), and draw on reuse and recovery principles (Esrey et al, 2001). In theory, these affordable and flexible systems are also more adaptive to ongoing urban demographic and infrastructural shifts (Rose, 1999; Tilley et al, 2008). Sustainability trends further augment these tendencies, as low-tech options are often considered to be more ecologically sound.

Even with considerable effort towards these ends, and despite the reputed benefits of many proposed systems, sanitation projects targeting impoverished areas remain marked by high failure rates-estimates suggest that between $30 \%$ and $70 \%$ of all sanitation projects globally fail within a few years of implementation ${ }^{2}$ (McConville and Mihelcic, 2007; World Bank, 2003). It is commonly held that these failures are in part due to insufficient community participation and acceptance (Katukiza et al, 2010; O'Reilly, 2010; Rodgers et al, 2007; Sohail et al, 2005). With respect to dry or no-flush solutions in particular, some authors note that low acceptance rates suggest that users may consider these systems to be culturally or contextually inappropriate (Cosenza et al, 2011; Jewitt, 2011; Rosenquist, 2005).

In our analysis, we build on these discussions by exploring how features of proposed sanitation systems may clash with users' urban sanitation imaginaries, including hygiene norms, senses of how infrastructure should look, what inputs should be required, and how it should feel to use. We suggest that participation in this imaginary is a central marker of citizenship and belonging in an urban context and thus has significant ramifications not only for user acceptance, but also for the socio-political dynamics inherent to any discussion of sanitation and hygiene. Our conception of the urban sanitation imaginary draws on other framings of the 'imaginary', (e.g. Castoriadis, 1994; Strauss, 2006), notably Taylor's definition as a "common understanding that makes possible common practices and a widely shared sense of legitimacy" (Taylor, 2002, p.106). As Taylor explains, this imaginary is shaped by social and cultural order, and is a means of delineating accepted norms of behavior and conduct, including shared notions of transgressions or taboo (in this sense, imaginary does have shared meanings with broad definitions of culture, or socio-cultural norms).

Applying the concept of the imaginary to urban sanitation, we explore how urban dwellers (in our case, specifically residents of Villa Lamadrid in Greater Buenos Aires) imagine appropriate sanitation for their context. We forward that practices of citizenship can be understood as acceptance of, and participation in, shared social imaginaries. In this vein we rely on authors who have worked to broaden the notion of 'citizenship' beyond a set of basic legal rights and responsibilities, to look at the larger social,

\footnotetext{
${ }^{2}$ As few interventions are actually monitored long-term after implementation, this data is based on a relatively limited sample size (Bliss and Bowe, 2010; Fogelberg, 2009; Thode et al, 2011).
} 
political, and economic processes and systems of inclusion and exclusion in a society (Agarwal, 2010; Harris, 2009; Marston and Staeheli, 1994; Roy, 2009a; Staeheli and Cope, 1994). Citizenship, it is argued, is performed, enacted, and extended through participation in a myriad of accepted daily social practices, which together indicate belonging in a society. Participation in these accepted practices takes on a moral weight, indicating who is acceptable, who counts, whose rights matter, and whose do not (Holston and Appadurai, 1998). Markers of citizenship and belonging can be read through infrastructural connections (see: Bakker, 2010; Chatterjee, 2004; Gandy, 2011; McFarlane, 2008b; McFarlane and Rutherford, 2008; Swyngedouw, 2004), participation in acceptable hygiene practices (see: Douglas, 1966; Ross, 1995; Vigarello, 1988), or through broader senses of belonging in urban life (see: Cunningham, 2011; Kaika, 2005; Pine, 2010; Zukin et al., 1998).

Buenos Aires is a particularly interesting context in which to explore linkages between sanitation, hygiene imaginaries, and processes of belonging-all elements strongly influenced by the city's colonial roots (Keeling, 1996). In particular, an emphasis on 'purity,' often referenced in relation to European sanitation practices and norms, has contributed to an emphasis on cleanliness practices as part of Argentinean, and particularly porteño ${ }^{3}$ identity (Joseph, 2000; Meik, 2011; Sutton, 2008). With concern over public health issues in new urban spaces following closely on the heels of the industrial revolution, Buenos Aires actively took part in the sanitation revolution happening in Europe by constructing centralized water and sewerage infrastructure at the end of the 19th century (Meik, 2011). The centralized, water-borne sewerage model in which infrastructure is hidden in walls and underground (Gandy, 2006) produces and permits the luxury of invisible sewage management, removing the user from any process beyond the flushing of the toilet handle (Black and Fawcett, 2008; George, 2009; Hawkins, 2006). As has been discussed for several European examples, participation in these water intensive hygiene practices took on moral weight as a means of demonstrating citizenship and moral uprightness in protecting public health (Bakker, 2010; Swyngedouw, 2004; Vigarello, 1988).

In addition to the city's colonial roots, its more recent past also lends interesting nuances to processes of citizenship in relation to water and sanitation infrastructure and access (Loftus and McDonald, 2001; Spronk, 2010) In the early 1990s the city of Buenos Aires was looked to as an urban center at the forefront of the growing neoliberal movement to privatize utilities and management of urban infrastructure. From 1993 to 2006 disparities in service access grew under the private enterprise Aguas Argentinas, which held the concession for water and sewerage service provision for most of Greater Buenos Aires. Payment for the expansion of water and sewerage networks fell largely onto those who could least afford to pay - poorer communities who required new connections (Loftus and McDonald, 2001). In the midst of these increasing differences in access to urban services, Néstor Kirchner's 2002 presidential campaign promised

\footnotetext{
${ }^{3}$ Porteño, or 'people of the port,' is the Argentine word for a resident of Buenos Aires, signifying the historic feeling that those in Buenos Aires "descended from the boats" (Sutton, 2008). Though it is traditionally used to refer only to residents of the Federal District (the capital of the province) (Keeling, 1996), here we use it to refer to the idealized citizen of Buenos Aires.
} 
reform by making these services once again the domain of the state. The campaign pushed an anti-privatization message and forwarded a vision of more equitable living conditions with focus on government support and responsibility. State service provision was thus connected historically and discursively to equity concerns, including a focus on incorporation of informal settlements into the modern urban fabric and life enjoyed in the more established neighborhoods of the city.

Our contribution here examines what attention to the urban sanitation imaginary offers to urban and development planning challenges. We do this through close empirical investigation in the context of Villa Lamadrid, a low-income community in Greater Buenos Aires (Figure 1). We find that the urban sanitation imaginary in this neighborhood centers on a sense that appropriate involvement in sewage management should involve the flush of a toilet-no more - with considerable emphasis on state responsibility for infrastructural management and provision. We develop this argument through a careful look at respondents' concerns and questions related to a dry urine diversion toilet (UDDT) - a system that many propose as technologically, economically, and biophysically suitable and sustainable for a context such as Villa Lamadrid. 


\section{CONTEXT: DEMOGRAPHICS AND GEOGRAPHY}

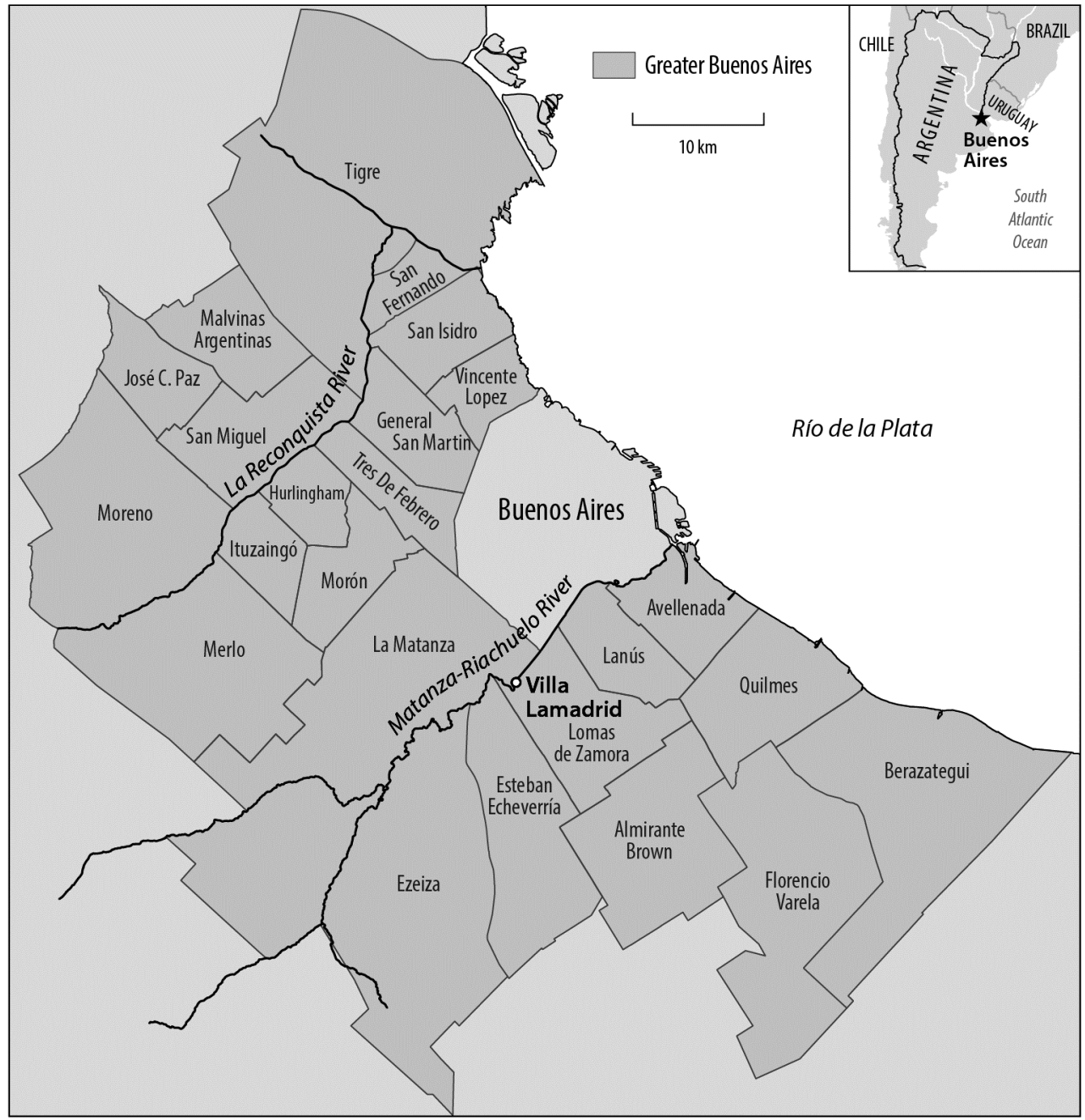

Figure 1: Map of the 24 municipalities that make up Greater Buenos Aires, the City of Buenos Aires (marked in a lighter shade), and Villa Lamadrid (marked with bold typeface) in Lomas de Zamora -the site of our study

Villa Lamadrid is a neighborhood in the municipality of Lomas de Zamora, one of 24 municipalities that together make up Greater Buenos Aires, Argentina. It is located in Cuartel IX, the sector of Lomas with highest population density and the majority of the municipality's informal areas (Municipality of Lomas de Zamora, 2012). The neighborhood's estimated population is between 5,500 and 6,000 people, with nearly $30 \%$ under the age of 20 (Medicos del Mundo and Foro Hídrico, 2011).

Villa Lamadrid consists of two major sections: the formal neighborhood, founded in 1906 (areas known as 'barrios populares'; Municipality of Lomas de Zamora, 2012), and the more recent informal areas known as 'villas,' constructed along the banks of the 
extremely polluted Matanza-Riachuelo River and its tributaries. This study focuses mainly on the older, more formal sections of the neighborhood-located in low-lying and flood-prone marshland. Homes are cement or brick and most are connected to municipal water, electricity and gas services but lack access to centralized sewage infrastructure. 


\section{SEWAGE MANAGEMENT IN VILLA LAMADRID}

The majority of residents of Villa Lamadrid's barrio popular have flush toilets connected to septic tanks. In the absence of a centralized treatment system, households generally pay for their septic tanks to be pumped out by service trucks (though at times this does not occur, and they leak or overflow, as discussed below). Household greywater is discharged directly into zanjas - open ditches approximately $30 \mathrm{~cm} \times 60 \mathrm{~cm}$ which border every street in the neighborhood and transport greywater and storm water to the bordering Matanza-Riachuelo River. Technically, this system meets the Joint Monitoring Program's criteria for improved sanitation ${ }^{4}$. For a variety of reasons, however, the setup far from accomplishes the goal of a system that "hygienically separates human excreta from human contact" (JMP, 2012: 33). First, the groundwater table in the area is extremely high, due to the area's low-lying position in a floodplain as well as several additional factors that exacerbate the problem. This leads to minor, and at times major, flooding during rain events, in addition to the almost constant presence of standing water in streets. Groundwater seepage into tanks also results in septic tanks filling very quickly, meaning they must be pumped regularly (at considerable cost), or overflow into residents' yards as well as into sidewalks, zanjas, roads, and public spaces-often mixing with standing water, particularly during rain events. The price for an average septic tank servicing from the pump truck was quoted by interviewees as around $\$ 260$ Argentine pesos, equivalent to approximately \$65 USD-representing a significant portion of income for neighborhood residents (Medicos del Mundo and Foro Hídrico, 2011). Even if residents are able to invest in occasional servicing, pumping does little to alleviate the problem of septic tanks refilling quickly due to groundwater infiltration. These conditions correspond with other studies of septic tank-based systems in urban areas with high groundwater levels (Brikke and Bredero, 2003; Kulabako et al, 2010).

Further to this, several of our interviewees claimed that some residents empty their septic tanks, or even connect their toilet pipes directly, into zanjas to avoid service costs. Our own observations confirm that many zanjas clearly contain feces. Complicating this picture further is the fact that drinking water is often transported to homes via PVC-tubes placed in the zanjas-suggesting the considerable risk of pathogen spread when tubes are compromised. Given this situation, it is likely that the occurrence and spread of pathogens in Villa Lamadrid is similar to, or even worse than, that of communities practicing open defecation. Nonetheless, the presence of flush toilets in homes makes end-user experiences of sanitation significantly different from open defecation in terms of privacy, senses of hygiene and symbolism of modernityissues we return to in the discussion below.

\footnotetext{
${ }^{4}$ The Joint Monitoring Program for Water Supply and Sanitation is a partnership between the World Health Organization and UNICEF tasked with monitoring progress toward drinking water and sanitation goals (JMP, 2012). Sanitation systems that are piped into septic tanks and not shared between households, as in Villa Lamadrid, meet the JMP's technical specifications for 'improved sanitation.' Some authors have contested the JMP's definition of 'improved sanitation' as it largely disregards cultural and local perspectives of what constitutes a workable and acceptable sanitation solution (Carter, Tyrell, and Howsam, 1999; Mehta and Movik, 2011).
} 
Construction costs of water-borne, centralized sewerage infrastructure would be extremely high in Villa Lamadrid owing to the same hydrological conditions that render the current septic system ineffective. Simply put, sewer pipes do not function well in marshland. This is one of many challenges facing the city's planned mega-sanitation project that aims to provide connections by 2020 to the 3.5 million inhabitants of Greater Buenos Aires presently lacking connection to centralized infrastructure (AySA, 2006). Even though Villa Lamadrid is one of the areas in largest need, it is currently slotted to be among the last communities to receive service (Interview by research team with a lead project engineer, Oct 2012). Members of a local community group told us that the state has continued to promise improved service to the neighborhood "in the near future"-a promise that seems dubious at best given the technological, topographic and political realities, and a continual string of postponements in project construction. Thus the future of sewerage infrastructure in Villa Lamadrid remains unclear. 


\section{METHODOLOGY}

Our study in Villa Lamadrid focused on lived experience and perceptions of sanitation and other community issues among neighborhood residents; most conversations took place over three months of fieldwork between September and December of 2011. A community leader assisted as a point of entry to the community, introducing us to other community members. Our visits to the neighborhood included attending a number of community meetings focused on local water and sewage issues, 36 semi-structured interviews with a diversity of neighborhood residents, as well a community-led participatory video project (discussed further below). The majority of interviews were with long-term and Argentinian-born residents living in Villa Lamadrid's barrio popular. It was harder to make connections with people who had recently arrived to the neighborhood and were living in informal sections of the area, likely due to the precarious nature of their working and living conditions.

Interviewees were asked to comment on sewage management systems designed for impoverished urban and peri-urban contexts; among these was a waterless urine diversion system (UDDT) with twin drying pits (see Figure $2 a)^{5}$. The systems were selected from a report by the Swiss Federal Institute of Aquatic Science and Technology (EAWAG), which synthesizes sanitation technologies for poor urban, peri-urban, and rural contexts (Tilley et al, 2008) ${ }^{6}$. The UDDT system is frequently forwarded as viable for peri-urban communities (e.g. Katukiza, 2010), as well as for flood prone areas with a high groundwater table (Tilley et al, 2008) - two factors that together suggest that a UDDT system might be suitable to the infrastructural and topographic conditions of Villa Lamadrid. We presented images to the interviewees and provided a brief explanation of how the system functions and what procedures are necessary for correct usage. We then asked for interviewees' opinions, whether they thought that any of the proposed systems would be suitable for Villa Lamadrid, and if not, what implementation obstacles they imagined.

\footnotetext{
${ }^{5}$ The toilet bowl of the UDDT system has two compartments, a smaller hole near the front for urine, and a larger hole near the back for feces. There is no flushing involved. Urine drops directly into a storage container below the toilet bowl and is stored for at least one month to adequately sanitize it for crop application. The urine can then be diluted with water and used as fertilizer for plants or garden plots. The feces falls into a drying vault positioned beneath the seat and a small amount of drying material (ash, sawdust, soil, lime, etc.) is thrown into the vault after each use to facilitate drying and reduce odor. The solids are stored for six months to allow for dehydration and ensure elimination of pathogens. During this time the solids turn into a nutrient rich white powder, which can be used as a soil amendment (Tilley et al, 2008).

${ }^{6}$ It should be noted that the Compendium specifically states that it does not to address the "social-cultural elements of sanitation planning" (7). Our purpose here is to elaborate our understanding of the socialcultural components of sanitation with the aim of addressing the high failure rate in urban sanitation interventions.
} 


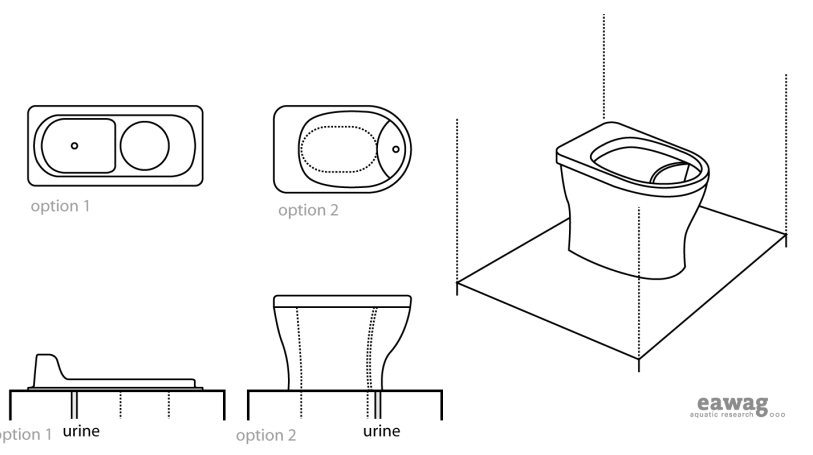

Figure 2a: Images of the urine diversion toilet; Credit left to right: Eawag, 2008; Fam, 2012; Images reprinted with permission under Creative Commons Share Alike License
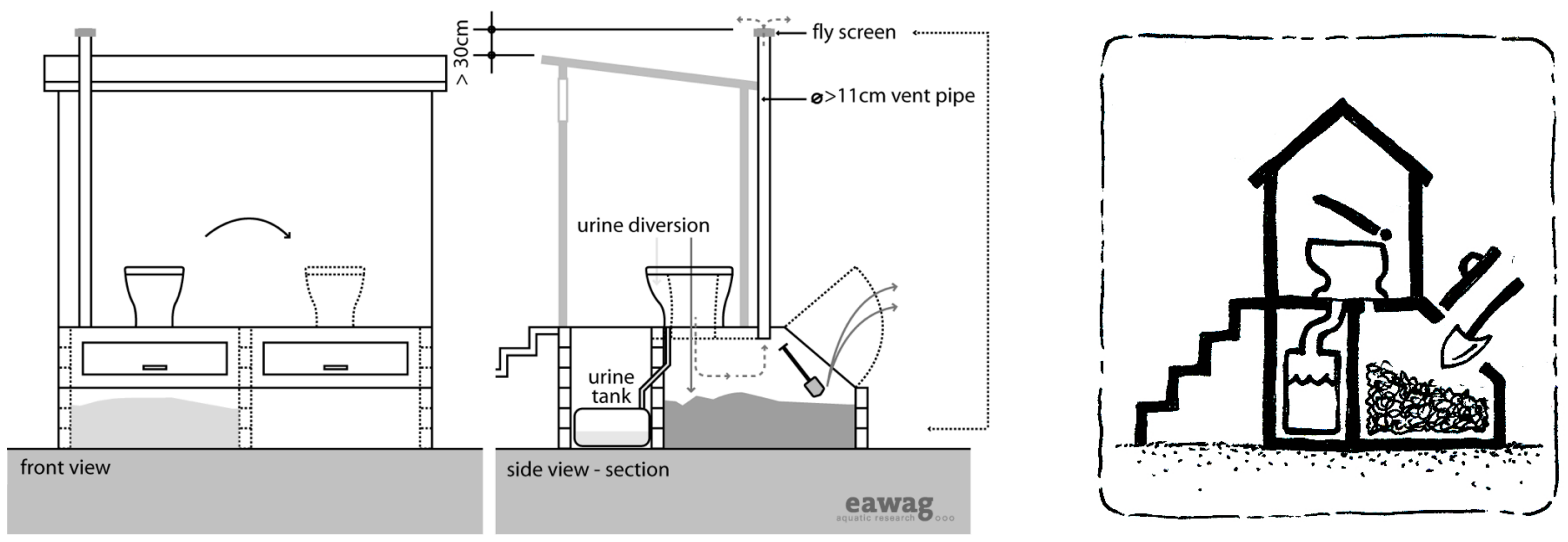

Figure 2b: Images of the dehydration vault; Credit left to right: Eawag, 2008; Akvopedia, 2009; Images reprinted with permission under Creative Commons Share Alike License

Our discussion that follows is largely based on responses to the UDDT, drawing on both verbal and non-verbal reactions to this dry technology. As one might expect, and as commonly noted when dealing with matters related to excreta (Black and Fawcett, 2008; George, 2009; Hawkins, 2006), respondents reacted to these conversations with polite mild surprise or embarrassment (raised eyebrows, a pause in movements, nervous laughter, etc...), amusement (a smile, a joke etc...), as well as distancing achieved discursively and through body language-as if to remove themselves from the conversation. At no time were these reactions strong enough to actually stop the interview. We consider all of these reactions to be important in our analysis. 


\section{REACTIONS TO THE DRY SANITATION SOLUTION}

At the center of our participants' urban sanitation imaginary was a feeling that a citizen should be disassociated from their excreta and related management processes, and this management should be invisible beyond flushing the toilet. From conversations with participants we have identified four cornerstones of this imaginary, each an aspect of how interviewees conveyed things "should be" in response to sanitation queries generally, and the UDDT system. First, an urban citizen does not physically or mentally engage with their shit or its management. Second, flushing is the iconic symbolic of an urban sanitation system, and dry systems are consequently fundamentally inappropriate in an urban context. Third solutions that require the user's engagement with their shit and its management signify rural, underdeveloped, and backward lifestyles, and as such have strong negative connotations for residents. Fourth, and finally, urban sanitation service is a state responsibility, not a local one. Therefore, systems that place management responsibility at the local or household level are inappropriate in the urban context.

Below we provide further detail to flesh out each of these four themes.

\section{Urban citizens do not engage with their shit}

While respondents agreed that there was a problem with the overflowing septic tanks, lack of sewers, and inundated streets, they frequently distanced themselves from the issue by invoking geographical distance:

Luckily here it doesn't flood, that stuff doesn't overflow into the street. The problem is over there, they have problems because when it floods the fecal matter flows into the street, because there are septic tanks. /../ Here, luckily, we don't get flooded... so it is not unhygienic here, where as over there it is. (Interviewee \#9, emphasis added)

When we asked where 'over there' was, it became evident that this interviewee was referring to a location two blocks away. Another similarly described the flooding as so geographically distant that it did not affect them personally:

It depends on what zone the house is, whether there is more or less groundwater. Luckily, I am fine. (Interviewee \#34)

While terrain varies in Villa Lamadrid, resulting in some areas flooding more quickly than others, the neighborhood covers a small area so that residents are bound to encounter flooded streets and feces-contaminated zanjas at some point, on the way to local shops and services, or traveling to other parts of the city. Narratives describing the sewage problem as geographically distant provide a rhetorical sense of distance between one's own body [or home] and shit. This discursive accomplishment serves to separate the self from the excreta, maintaining personal cleanliness, and assigning the problem as one associated with 'Other' residents, particularly new migrants (Author, in process). 
Interviewees also distanced themselves from the sanitation problem by demonstrating their lack of knowledge on the issue. We encountered a general hesitancy to comment on the proposed systems and many showed an eagerness to make it known that when they spoke, they did so with very little knowledge on the subject. One woman explained,

To me it seems that without water it is unhygienic, but what do I know?/.../ Of course I don't know anything... I don't know. (Interviewee \#19, emphasis added)

The keenness to make it known that they spoke only for themselves seemed to be a way that participants demonstrated their lack of expertise on local sewage management, that these were not things they had to think or know about in the their daily lives, thus signifying their participation in urban life and citizenship. As we discuss below, there was an overarching sense that that ordinary citizens in fact have the right to be ignorant of the management process beyond the flush of the toilet as this was seen as the domain of the state. Apart from distancing oneself from excreta, the discursive maneuvers can also be interpreted as a way of asserting that while they might be poor, they too have a right to be ignorant of sanitation as much as someone in a more affluent part of Buenos Aires, or indeed, from the industrialized North.

Not unexpectedly, a sense of unease regarding why they were being asked about this technological option was evident in several discussions. Several interviewees responded to queries about the UDDT by asking us (the researchers) whether we used these dry systems ourselves. When we asked one interviewee, a woman in her late 60s, whether she thought a dry system could work in Villa Lamadrid she responded emphatically,

I \#27: But do you have these (in Canada)?

$R:$ In some areas.

I\#27: People use them'?

R: Some.

I\#27: Where, for example? (Interviewee \#27)

It was not possible to tell whether the line of questioning came from surprise, interest, courtesy, or suspicion. What seems most important with this question is the challenge offered: Do 'we' (the researchers, the Westerners, the North Americans) use this technology? And if not, why might it be recommended for them? Indeed, the implicit question seemed to be: if such a solution is inappropriate for a more developed place, why would it be appropriate here?

Some specific aspects of the UDDT made interviewees very uncomfortable including the required physical proximity and interaction with excreta. This became particularly clear when we discussed the solid end products that must be manually removed from the drying pits; this was visually signaled by the inclusion of shovels in the presented images (Figure 2b). When we asked one interviewee, a woman in her mid-50s who had been born in the Argentinian countryside but had lived most of her life 
in Villa Lamadrid, whether she would feel comfortable with manual emptying of the dried fecal matter, she responded with considerable hesitancy,

I don't know. I don't have any idea, the truth is that I can't tell you, "I will do this and that's it." Do you see? But I think for the first time I would call someone to do it for me, for the first time, to see how it needs to be done. (Interviewee \#26)

Another interviewee started giggling when we asked this question,

$R$ : Do you think you could empty it yourself, or would you pay someone to do it?

I\#22: [giggling] I would pay someone.

$R$ : Because it is dirty?

I\#22: [still giggling] Yes, yes.

She continued to giggle for a while in our conversation. Finally we asked,

$R:$ What seems so funny?

I\#22: I don't know. (Interviewee \#22)

Other interviewees even made jokes about the suggestion that they would empty their own shit and urine. Listening in on a conversation we had with a mother in her 50's, her son compared the urine collection bucket to a bedpan for invalids, (in this excerpt, I' indicates the son of our interviewee, a man in his mid-20s),

I\#26: And when this is full, what do you do to empty it? How do you take it out?

l': Have you seen what happens to the old people? Their piss has to be carted away. (Interviewee \#26)

These comments made clear the assertion that technologies which required bodily engagement with one's own shit were not 'solutions' at all, but rather inappropriate, uncomfortable, or at times, laughable.

The required proximity to feces and its management also made this system seem unhygienic, despite assurances that the drying of fecal matter would eliminate pathogens. Considering that at present fecal matter mixes with storm water during storm events, direct contact with feces is arguably impossible to avoid in many residents' day to day lives. We believe interviewees made a clear distinction between the current sanitation situation, which was ascribed to state negligence (discussed below), and a planned sanitation solution that required persistent proximity to one's feces, particularly in one's own living space. All told, we had the impression that it was considered somewhat insulting to suggest that these residents might, or should, consider a dry sanitation system-whatever its purported benefits might be for broader financial or sustainability goals.

\section{An appropriate system requires flushing}

Nearly every interviewee made comments demonstrating that they consider flushing to be a non-negotiable feature of an appropriate sewerage system. Flushing conferred a 
sense of hygiene, and distance from excrement.

The feeling that the presence of water made a toilet system more hygienic and clean was accentuated by the repeated preference among interviewees for another sanitation system presented, a pour-flush toilet. When we asked about this preference interviewees frequently expressed that since this system utilized at least some water it felt more hygienic than the dry UDDT system,

First, because it seems hygienic because of the water. (Interviewee \#19)

Apart from cleanliness, the ease of a waterborne or flush system was often emphasized. As noted by one respondent (a woman in her 40s),

The easiest [solution] is to have a sewer; you go to the bathroom, push the button, and there is nothing more to do. (Interviewee \#19)

Many women brought up the issue that without water and flushing, keeping the toilet clean would require significantly more work. Noting the intimate contact with feces that might be required to clean the dry system, one woman in her 60s commented:

This would be very problematic, because you can't use a scrubbing brush to keep it clean if it is dry. (Interviewee \#17)

Similarly, another woman commented,

You would have to clean it continually. Because if there are many people in the family, like we are six, it is used 6 times a day, and more... And every time a person uses it, the glove has to be put on to clean it [laughs]. (Interviewee \#26)

Given that at present residents have access to running water with WCs in the bathrooms, and are aware that others in the city of Buenos Aires (and indeed around the world) have conventional flush systems, respondents felt that moving from the current system to a dry technology would be moving backwards-a reinforcement of the sense that this community is excluded from the civic life of greater Buenos Aires, or from a broader notion of a modern urban or cosmopolitan citizenry.

\section{Sanitation solutions that require direct user engagement signify rural, underdeveloped, and backward lifestyles}

The implications of a dry sanitation system seemed in opposition to reasons many residents had migrated to the urban area-to seek out a better life. Sanitation in a rural context was associated with additional work burden as well as personal and bodily engagement in the sewage management process-both attributes required by the presented dry system.

Most residents we interviewed had lived in Villa Lamadrid for a considerable time. They described the area's progression from a relatively informal and underserved settlement towards greater legitimacy and recognition as a neighborhood, symbolized in attaining many municipal services throughout the late 60's and 70's. The neighborhood's past was associated with resource scarcity, particularly of water, lack of infrastructure, and additional work burden, 
When we were kids we washed ourselves in washbasins, and then used this same bath water to flush the toilet, because there wasn't any water. There was no connection to the water system and you had to carry water for several blocks, so you were careful to conserve it. (Interviewee \#19)

As the UDDT system centers on reducing water usage and hinges on personal involvement in management, it carried associations with the neighborhood's past.

Several of our interviewees who were born in the Argentine countryside had experience with dry toilets. Sometimes these participants suggested that since the idea of a dry toilet was not novel for them, they would be more willing to use it again. However, more common was a sense that one should not 'return,'

From my point of view, going back to living in the country would be very difficult for me now. I am accustomed to this [urban lifestyle]. (Interviewee \#26)

Differentiating from a rural past was expressed as key to fulfilling the goals that had brought them to leave their rural areas to undertake a new life in metro Buenos Aires.

In some interviews we discussed the fact that the dry system would be more cost-effective if constructed separate from the house (this was due to the fact that retrofitting an existing home with drying chambers appeared to be very costly). Even so, the prospect of a separated or detached toilet was not something many interviewees were willing to consider, not least because it was reminiscent of an outhouse, and of a less comfortable past.

R: Do you think that people who have an indoor bathroom would change and use...?

I\#19: Outside? No, I do not think so. I think that it is much more comfortable to have it inside. We had a bathroom outside. When I was young we had an outdoor bathroom... we used to use it like that, the bathroom outside the house, facing the courtyard... and it was cold if you had to use it at night. It was uncomfortable. (Interviewee \#19)

Accepting a dry toilet system felt synonymous to interviewees with foregoing the comforts promised by urban life. It also seemed that these sanitation possibilities represented yet another way their community could be further marked as excluded from the urban citizenry of Buenos Aires. In contrast, it was very clear that connection to the city's centralized sewer system was seen as an important step towards becoming a legitimate neighborhood, and actualizing the urban life imaginaries they were moving towards.

\section{Urban sanitation service is a state responsibility - not a local one}

Our conversations made very apparent that residents read sanitation struggles as signs of state negligence and failure. Early on in our conversations we asked interviewees what they thought were appropriate solutions to the problems of flooding and septic tank overflows in the neighborhood. Nearly all participants responded that the solution should be sewers-more specifically centralized, waterborne, 'end-of-pipe' sewerage provided by the state. When asking one interviewee, an older gentleman who owned a 
neighborhood store, whether he thought there were concerns in the neighborhood regarding sanitation, he responded,

Yes, there are concerns, but you aren't going to be able to fix them. This has to be the state only: to build sewers, this is a big project. (Interviewee \#17)

On several occasions we asked members of a neighborhood organization concerned with local environmental and health issues whether they had considered local sanitation solutions. Responses made it clear that management of sanitation services in Villa Lamadrid is, and should be, a state responsibility, not a local one. It was argued that the only thing the local community could (and should) do about the situation was to find ways to pressure the government to build the promised centralized infrastructure. The solution they were pursuing was the construction of a smaller and temporary treatment plant, known as Fiorito, which would offer sewerage service to a couple hundred thousand residents in the area. This would save Villa Lamadrid from having to wait for the planned mega-facility.

Interviewees frequently linked the lack of sanitation service to the neighborhood's history as a marginalized settlement in which residents have had to repeatedly lobby for access to services that other communities appear to enjoy as a matter of course. Many interviewees described that 'things are different here,' meaning that general laws and expectations of life in Buenos Aires (or for urban life generally) do not always apply to life in Villa Lamadrid. Citing a local government that is neglectful and cannot be trusted, interviewees made comments such as:

The governor of our neighborhood doesn't care about us. None of them that we have had have done anything for our neighborhood." (Interviewee \#6)

Or,

I have been waiting all of my life [for sewerage connection]. They are always saying that it is coming, but do you see how the politicians are? "It will come next year," "next year," "next year"[they say], and it never comes. (Interviewee \#19)

Participants also frequently compared Villa Lamadrid's current conditions with those in neighboring communities to highlight their exclusion.

There are still no sewers here. In central Lomas there are sewers. I think they are going to install sewers in Budge now, which is 5 or 10 minutes from here... We will see if this is just a promise, or if they are going to do it. It depends on the politicians... They say they will, that they will install the sewers, so fingers crossed [laughs]. (Interviewee \#8)

A further example of the sense of being ignored was illustrated during a collaborative video project we made with residents of Villa Lamadrid. At the request of a neighborhood group concerned with community health issues we filmed and edited a short video detailing the organization's work. Neighborhood residents guided the filming process, pointing out and narrating some of their key concerns through neighborhood walks. These extended much more broadly than sewage management, including solid waste burning and the proximity of high-tension cables. Each issue focused on lacking 
public infrastructure, or inadequate maintenance. The resulting health impacts were repeatedly narrated as the result of state negligence. After creating a first cut of the video we screened it to the community group and a wider community audience, soliciting feedback and advice. From these screenings came the telling title selected for the video: "Crónica de un estado ausente" - "Chronicle of an absent state."

In all of these examples we see the iteration of a common theme: the solution to sanitation issues does not rest on the local community, but rather the state. However, the state is unreliable, neglectful, perhaps even corrupt, and has been largely absentaccounting for the continued lack of infrastructure. The neighborhood's ongoing sanitation problem consolidates for residents a sense that they are not counted as valued citizens of the city nor of the state. Given this tight linkage between sewerage provision and inclusion by the state, there is a sense that local solutions would be an acceptance and entrenchment of current exclusion and neglect-directly linking sanitation technology, infrastructure and notions of citizenship. 


\section{DISCUSSION: A CITIZEN'S SHIT IS INVISIBLE}

Our goal with this research was to explore participants' urban sanitation imaginaries with the aim of understanding how they might define appropriate sanitation solutions for their households and communities. We find that the core of the sanitation imaginary in Villa Lamadrid is that a citizen has the right to expect disassociation from their excreta and its management: disassociation to the point of invisibility. In brief-one expects their involvement with their shit to end with the flush of the toilet, eliminating waste from one's life.

The UDDT made interviewees uncomfortable. Many disliked that it made management of excreta personal and required bodily engagement. The lack of water was also deeply problematic. Flushing was considered a nonnegotiable feature of an appropriate sanitation system, associated with feelings of cleanliness and an urban life distanced from an impoverished and rural past. Our findings here are consistent with other studies that have suggested that flush toilets are symbols of success and modernity, particularly for rural-to-urban migrants (Benidickson, 2007; Black and Fawcett, 2008; George, 2009; Jemsby, 2008). Further, Hawkins (2006) describes flushing as a practice whereby feces and urine are moved from the private space of the home into the public space of the street, expunging individual responsibility by anonymizing waste and transforming it into a public concern. In our study context the city of Buenos Aires has long been a symbol of Argentina's modernity, particularly given the city's European roots. Thus migration to the city is not only an economic decision, but also a symbolic movement (Keeling, 1996). Likely due to these linkages, the suggestion that residents give up their flush toilets in favor of a dry system felt like giving up the possibility of full citizenship in modern urban life, despite assurances that the proposed system would be more hygienic, financially reasonable, or ecologically sustainable.

In addition to the emphasis on flushing, respondents frequently suggested that an appropriate sanitation system for their neighborhood should be centralized and statemanaged, minimizing their involvement in management processes. To support this claim, interviewees drew on notions of what existed elsewhere, in Canada (where the research team was from), in the industrialized North, as well as in other neighborhoods of Buenos Aires. These invocations described how sanitation 'should work' for a rightsclaiming citizen of Buenos Aires-linking notions and enactments of urban citizenship (see also: Penner, 2010; Swyngedouw, 2004).

Recall our earlier discussion of the impact of centralized and hidden sanitation infrastructure and its implications for hygiene norms and demonstration of virtuous behavior (Bakker, 2010; Benidickson, 2007; Gandy 2006; Vigarello, 1988). Writing about the context of modern Mumbai, Appadurai (2002) suggests that the privacy conferred by hidden sewerage infrastructure is a marker of citizenship; conversely, when there is no privacy, and excrement and excretion are laid bare to the public eye, as it often is for residents of informal settlements, this erodes citizenship and renders one invisible to the state. Given this context, household level sanitation solutions that 
rely on embodied involvement in personal waste management sit an interesting intersection. While they may reduce the open presence of shit in the streets of Villa Lamadrid, and reduce pathogen contact for residents, they make shit management a visible process in which proximity to excreta not only continues, but is intentional, indeed planned. For many participants, giving up on the possibility of a sanitation solution that is consistent with their urban sanitation imaginary would also be to accept one's status as a second-class citizen. 


\section{CONCLUSION: HOW THE URBAN SANITATION IMAGINARY MAY HELP GROUND OUR SANITATION IDEALS}

Empirically, this work highlights several insights specific to the potential of sanitation technologies in Villa Lamadrid; interviewees emphasized the importance of flushing, distance from management processes, and a sense that sewerage is a state responsibility. Conceptually, this work further develops the notion of the urban sanitation imaginary which foregrounds linkages between sanitation infrastructure and urban living, citizenship, and justice - issues relevant to any proposed sanitation 'solution.' These concerns are clearly relevant to this case study, and are also suggestive for sanitation in urban regions across the globe.

In light of the growing literature that argues that local, citizen-fostered projects offer the most sustainable and effective solutions to sewage management, particularly for low-income and marginalized urban communities (Burra et al., 2003; Hasan, 1990; 2006; Satterthwaite et al, 2005; UN Habitat, 2003), it is notable observation that the idea of local initiatives was met with suspicion and skepticism by many of our interviewees. Responses largely deflected 'localized' solutions that place the community as the site of concern and source of solutions. Again, this sense of distance is important-residents wanted to disassociate their shit from their local geography, as well as to distance themselves from responsibility for it.

Though so-called 'ecological sanitation' systems are applauded for being environmentally sustainable and providing technical means to address growing public health concerns, this work highlights how such solutions are never detached from broader socio-cultural and political issues. From an environmental justice perspective, it is clear that the promotion of household or local-level solutions in certain (impoverished) communities may be inherently problematic when compared against affluent urban communities where water-intensive, centralized, and linear end-of-pipe solutions have become the norm - unquestioned and undoubted. These end-of-pipe systems prioritize separation between individuals and their shit, often with this ideal taking precedence over ecological or economic efficiency (Black and Fawcett, 2008; George, 2009). As other development theorists have suggested, it is problematic to expect that the poor should have to participate in water delivery, sanitation solutions, or management of other basic services while others (particularly the rich) are not expected to do so (McFarlane, 2008a; Roy, 2009b; Swyngedouw, 2004).

In many ways the rationale of these proposed sanitation solutions makes good sense: the extensive costs that would be incurred in constructing waterborne, centralized sewerage infrastructure for the millions of urban dwellers currently not served are enormous. As a result, the target populations for dry, more ecologically sustainable sanitation systems are those not yet connected to centralized networks. Yet, we are suggesting here the need to take account of the ways that proposals for decentralized, low-tech solutions track against broader socio-political inequalities. Is it fair to prescribe marginalized urban dwellers household-level sanitation solutions, asking them to participate in intimate engagement with bodily waste that more affluent 
urban dwellers are not willing to undertake? On the other hand, does it make sense to continue building centralized, water-borne sewerage infrastructure that we know to be ultimately unsustainable?

A rapidly growing number of examples exist globally where recycle and reusebased sanitation solutions have been implemented on various scales (building, neighborhood, district) (e.g. Dockside Green, B.C. Canada, the Earthship Biotecture movement, and Hammarby Sjöstad in Sweden, (Dockside Green, 2014; Earthship, 2014; Hammarby, 2012). However, there exist important differences between these examples and prescribed decentralized solutions in marginalized urban communities, such as Villa Lamadrid. Ecovillages, and similar 'green' efforts, typically require little to no bodily or mental engagement in sewage management from users; management is undertaken by 'specialists' employed either by the state or those endorsing the project. As well, very few instances exist in which communities choose to implement fully dry solutions. A notable exception is China's Daxing Ecological Community, known as 'the world's biggest dry toilet experiment.' The community used UDDT toilets from 20062009, but the toilets were removed in 2009 due to odor and other complaints (Shan, 2012).

Attention to urban sanitation imaginaries is useful in pinpointing attributes of successful sanitation projects, and better understanding key sticking points where they may fail. Drawing on our case, we suggest that even if implemented on a small-scale, waste management processes must include broader support, and operate with the guidance of 'experts' or 'technicians,' rather than be left to individuals who have no other recourse. This is not to say that user engagement is impossible to sustain, yet there are clear obstacles to direct user engagement on multiple levels (notions of what is sanitary, or notions of justice and fairness given relative differences in sanitation infrastructure across communities). The urban sanitation imaginary also helps to foreground the association between the presence of water and a sense of cleanlinessan association that poses considerable challenge for dry systems.

Drawing on the specifics of the Villa Lamadrid case, we consider that the urban sanitation imaginary exposes deep problems in how we theorize, approach, and plan for sanitation in underserved urban areas across the globe. While we see great potential for new sanitation solutions, it is also evident that we must be cautious about beginning the attack on the enormous resource consumption inherent to centralized sewerage by preaching to the unsewered. Such an approach is not just, and unlikely to produce a change that will be taken up in the long-term. For Villa Lamadrid, regardless of the efficiency or actual hygiene of a presented system, it is unlikely to be sustainable if it does not address the larger issues and concerns of the community-those of belonging, citizenship, equity, and rights as urban dwellers. 


\section{REFERENCES}

Agarwal B, 2010, "Participatory Exclusions, Community Forestry, and Gender: An analysis for South Asia and a conceptual framework" World Development 29(10) 1623-1648

Akvopedia, 2009, "Dehydration Vault" 4 March, http://akvopedia.org/wiki/File:Icon_dehydration_vault.png

Appadurai A, 2002, "Deep Democracy: Urban Governmentality and the Horizon of Politics" Public Culture 14(1) 21-47

Morales, "Bolivians Piss in the Ditch' - Managing Wastewater with Narrative" (forthcoming)

AySA, 2006, Plan de Saneamiento de AySA 2006-2020 Agua y Saneamiento Argentinos S.A. (Buenos Aires)

Bakker K, 2010. Privatizing Water: Governance Failure and the World's Urban Water Crisis (Cornell University Press, Ithaca, NY)

Beall J, Crankshaw O, Parnell S, 2011, "Villains and Fixers: the Urban Victims, Poor and Johannesburg's Environment" Environment 26(4) 833-855

Benidickson J, 2007 The Culture of Flushing: A Social and Legal History of Sewage. (UBC Press, Vancouver, BC)

Black M, Fawcett B, 2008, The Last Taboo: Opening the Door on the Global Sanitation Crisis (Cornwell Press, London)

Bliss K, Bowe K, 2010, "Paths Forward for the Global Water, Sanitation, and Hygiene (WASH) Sector: A report of the CSIS Global Water Futures Project", Center for Strategic and International Studies, Washington DC

Brikke F, Bredero M, 2003, "Linking technology choice with operation and maintenance in the context of community water supply and sanitation: A reference document for planners and project staff' World Health Organization and IRC Water and Sanitation Centre, Geneva

Burra S, Patel S, Kerr T, 2003, "Community-designed, built and managed toilet blocks in Indian cites" Environment and Urbanization 15(2) 11-32

Carter R, Tyrrel S, Howsam, P, 1999, "The Impact and Sustainability of Community Water Supply and Sanitation Programmes in Developing Countries" Water and Environment 13(4) 292-296

Castoriadis C, 1994, "Radical Imagination and the Social Instituting Imaginary", in Rethinking Imagination: Culture and Creativity Eds G Robinson, J Rundell (Routledge, London) pp 136-154 
Chatterjee P, 2004, The Politics of the Governed: Reflections on Popular Politics in Most of the World (Columbia University Press, New York)

Cosenza A, Haxsen S, Sattler Y, Wucherpfennig K, 2011, "Sanitation Study: Evaluation of Dry Sanitation Systems in Namibia 2011" Ed. T Uhlendahl, Institute of Cultural Geography, University of Freiburg

Cunningham F, 2011, "The Virtues of urban citizenship" City, Culture and Society 2 3544

Davis M, 2004, "Planet of slums" New Left Review 26 5-34

Dockside Green, 2014, Dockside Green online Retrieved May 15, 2014, from http://www.docksidegreen.com/

Douglas M, 1966, Purity and Danger: An Analysis of Concepts of Pollution and Taboo (Routledge, NY)

Earthship Biotecture, 2014, Earthship Biotecture online Retrieved May 15, 2014 from http://earthship.com/

Eawag, 2008, "Compendium of Sanitation Systems and Technologies" Swiss Federal Institute of Acquatic Science and Technology (Eawag), Dübendorf, Switzerland

Esrey S, Andersson I, Hillers A, Sawyer R, 2001, "Closing the Loop: Ecological sanitation for food security" Publications on Water Resources SIDA, Swedish International Development Cooperation Agency, Mexico, http://www.gwpforum.org/gwpef/wfmain.nsf/Publications

Fam D, 2012, "Our ancestors recycled their urine: why shouldn't we?" ABC Science, 31 January, http://www.abc.net.au/science/articles/2012/01/31/3415550.htm

Fogelberg K, 2009, "Looking back to move forward in strength: monitoring of water system sustainability" Knowledge Management for Development Journal 5(3) 229245

Foppen J W, Kansiime F, 2009, "Integrated Approaches and Strategies to Address the Sanitation Crisis in Unsewered Slum Areas in African Mega-cities" Reviews in Environmental Science and Bio/Technology 8(4) 305-311

Gandy M, 2004, "Rethinking urban metabolism: water, space and the modern city" City 8(3) 363-379

Gandy, M, 2006, "The Bacteriological City and Its Discontents" Historical Geography 34 14-25

Gandy M, 2011, "Water as an object of enquiry" International Journal of Urban Sustainable Development 3(1) 132-133

George R, 2009, The Big Necessity: The Unmentionable World of Human Waste and Why it Matters (Metropolitan Books, New Cork, NY) 
Hammarby Sjöstad, 2012, Hammarby Sjöstad on-line Retrieved August 30, 2012, from http://www.hammarbysjostad.se/

Harris L, 2009, "Gender and emergent water governance: a comparative overview of neoliberalized natures and gender dimensions of privatization, devolution and marketization" Gender, Place and Culture 16(4) 387-408

Hasan A, 1990, "Community groups and non-government organizations in the urban field in Pakistan" Environment and Urbanization 2(1) 74-86

Hasan A, 2006, "Orangi Pilot Project: the expansion of work beyond Orangi and the mapping of informal settlements and infrastructure" Environment and Urbanization 18(2) 451-480

Hawkins G, 2006, The Ethics of Waste How We Relate to Rubbish (Rowman \& Littlefield Publishers, Inc., Lanham)

Holston J, Appadurai E, Eds., 1998, Cities and Citizenship (Duke University Press, Durham)

Jemsby C, 2008, "The most famous toilets in Uganda" Saniation NOW 4

Jewitt S, 2011, "Geographies of shit: Spatial and temporal variations in attitudes towards human waste" Progress in Human Geography 35(5) 608-626

Joseph G, 2000, "Taking race seriously: Whitemenss in Argentina's national and transnational imaginary" Identities: Global Studies in Culture and Power 7(3) 333371

JMP, Joint Monitoring Program for Water Supply and Sanitation 2012 "Progress on Drinking Water and Sanitation: 2012 Update"

Kaika M, 2005 City of Flows (Routledge, NY)

Katukiza A, Ronteltap M, Oleja A, Niwagaba C, Kansiime F, Lens P, 2010, "Selection of sustainable sanitation technologies for urban slums - a case of Bwaise III in Kampala, Uganda" Science of the Total Environment 409(1) 52-62

Keeling D J, 1996 Buenos Aires: Global dreams, local crises (Wiley, Chichester, NY)

Kulabako R N, Nalubega M, Wozei E, Thunvik R, 2010, "Environmental health practices, constraints and possible interventions in peri-urban settlements in developing countries-a review of Kampala, Uganda" International Journal of Environmental Health Research 20(4) 231-257

Loftus A, Mcdonald D, 2001, "Of liquid dreams: a political ecology of water privatization in Buenos Aires" Environment \& Urbanization 13(2) 179-199

Mamdani M, 1996, Citizen and Subject: Contemporary Africa and the Legacy of Late Colonialism (Princeton University Press, Princeton, NJ)

Marston S, Staeheli L, 1994, "Citizenship, struggle and political and economic restructuring" Environment and Planning A 26 840-848 
McConville J R, Mihelcic J R, 2007, "Adapting Life-Cycle Thinking Tools to Evaluate Project Sustainability in International Water and Sanitation Development Work" Environmental Engineering Science 24(7) 937-948

McFarlane C, 2008a, "Governing the Contaminated City: Infrastructure and Sanitation in Colonial and Postcolonial Bombay" International Journal of Urban and Regional Research 32(2) 415-435

McFarlane C, 2008b, "Sanitation in Mumbai's informal settlements: state, 'slum', and infrastructure" Environment and Planning A 40 88-107

McFarlane C, Rutherford J, 2008, "Political Infrastructures: Governing and Experiencing the Fabric of the City" International Journal of Urban and Regional Research Volume 32(2) 363-374

Medicos del Mundo and Foro Hídrico, 2011, "Resumen Preeliminar Barrio 2011", Buenos Aires, http://www.scribd.com/doc/71920539/Resumen-Preeliminar-Barrio2011

Mehta L, Movik S, Eds., 2011, Shit Matters: the potential of community-led total sanitation (Practical Action Publishing, Warwickshire)

Meik K T, 2011, Disease and Hygiene in the Construction of a Nation: The Public Sphere, Public Space, and the Private Domain in Buenos Aires, 1871-1910. Comparative Studies in Society and History PhD thesis, Department of History, Florida International University.

Mohit K, Ludwig H, 2000, "Appropriate technology for municipal sewage management in developing countries: Thailand case study" The Environmentalist 20 215-219

Municipality of Lomas de Zamora, 2012, Municipio de Lomas de Zamora online $\begin{array}{llll}\text { Retrieved } & \text { August } & 15 & 2012\end{array}$ http://www.lomasdezamora.gov.ar/epage.php?id=14

Nhapi I, 2004, "A framework for the decentralised management of wastewater in Zimbabwe" Physics and Chemistry of the Earth 29(15-18) 1265-1273

Niemczynowiez J, 1993, "New Aspects of Sewerage and Water Technology" Ambio 22(7) 449-455

O'Reilly K, 2010, "Combining sanitation and women's participation in water supply: an example from Rajasthan" Development in Practice 20(1) 45-56

Paterson C, Mara D, Curtis T, 2007, "Pro-poor sanitation technologies" Geoforum 38(5) 901-907

Penner B, 2010, "Flush with Inequality: Sanitation in South Africa" The Design Observer, 18 November, http://places.designobserver.com/feature/flush-with-inequalitysanitation-in-south-africa/21619/

Pine A, 2010, "The performativity of urban citizenship" Environment and Planning A 42 1103-1120 
Rodgers A, Ajono L, Gyapong J, Hagan M, Emerson P, 2007, "Characteristics of latrine promotion participants and non-participants; inspection of latrines; and perceptions of household latrines in Northern Ghana" Tropical medicine \& International Health 12(6) $772-82$

Rose G, 1999, "Community-Based Technologies for Domestic Wastewater Treatment and Resuse: Options for Urban Agriculture" Cities Feeding People Series 27 International Development Research Center, Ottawa, http://www.washcost.info/ docsearch/title/125784

Rosenquist L, 2005, "A psychosocial análisis of the human-sanitation nexus" Journal of Environmental Psychology 25 335-346

Ross K, 1995, Fast Cars, Clean Bodies (MIT Press, Cambridge, MA)

Roy A, 2009a, "Civic Governmentality: The Politics of Inclusion in Beirut and Mumbai" Antipode 41(1) 159-179

Roy A, 2009b, 'Why India Cannot Plan Its Cities: Informality, Insurgence and the Idiom of Urbanization" Planning Theory, 8(1) 76-87

Satterthwaite D, MacGranahan G, Mitlin D, 2005, Community-driven development for water and sanitation in urban areas: its contribution to meeting the Millenium Development Goal targets (International Institue for Environment and Development and Water Supply \& Sanitaiton Collaborative Council)

Shan W, 2012, "World's biggest eco-toilet project ends in failure" China Dialogue 7 July, https://www.chinadialogue.net/article/show/single/en/5068-World-s-biggest-ecotoilet-project-ends-in-failure

Sohail M, Cavill S, Cotton A P, 2005, "Sustainable Operation and Maintenance of Urban Infrastructure: Myth or Reality?" Journal of Urban Planning and Development 131(March) 39-49

Spronk S, 2010, "Water and Sanitation Utilities in the Global South: Re-centering the Debate on 'Efficiency"' Review of Radical Political Economics 42(2) 156-174

Staeheli LA, Cope MA, 1994, “Empowering women's citizenship” Political Geography 13(5) 443-460

Strauss C, 2006, "The Imaginary” Anthropological Theory 6(3) 322-344

Sutton B, 2008, "Contesting Racism: Democratic Citizenship, Human Rights, and Antiracist Politics in Argentina" Latin American Perspectives 35(6) 106-121

Swyngedouw E, 2004, Social Power and the Urbanization of Water (Oxford University Press, Oxford)

Taylor C, 2002, "Modern Social Imaginaries" Public Culture 14(1) 91-124

Thode A G, Landick K, Paterson K, Watkins D, 2011, "Analyzing Methods to Achieve Successful Development" International Journal for Service Learning in Engineering 6(1) $94-103$ 
Tilley E, Lüthi C, Morel A, Zurbrügg C, Schertenleib R, 2008, "Compendium of Sanitation Systems and Technologies" Swiss Federal Institute of Acquatic Science and Technology (Eawag), Dübendorf, Switzerland

UN Habitat, 2003, Water and Sanitation in the World's Cities: Local Action for Global Goals (Earthscan, London)

Vigarello G, 1988, Concepts of cleanliness: changing attitudes in France since the Middle Ages (Cambridge University Press, Cambridge)

World Bank, 2003, "Efficient, sustainable service for all? An OED review of the World Bank's assistance to water supply and sanitation" World Bank, Washington DC, http://documents.worldbank.org/curated/en/2003/09/2519895/efficient-sustainableservice-all-oed-review-world-banks-assistance-water-supply-sanitation

Zukin S, Baskerville R, Greenberg M, Guthreau C, Halley J, Halling M, Lawler K, Nerio R, Stack R, Vitale A, Wissinger B, 1998 "From Coney Island to Las Vegas in the Urban Imaginary: Discursive Practices of Growth and Decline" Urban Affairs Review 33(5) 627-654 